\title{
Android-Based for Fiqh Science Learning Innovation
}

\author{
Nizar Zakaria \\ Universitas Islam Negeri Maulana Malik Ibrahim, Malang, Indonesia \\ nz.iyank@gmail.com
}

\begin{tabular}{|c|c|}
\hline Article Info & ABSTRACT \\
\hline $\begin{array}{l}\text { Article history: } \\
\text { Received: July 14, } 2018 \\
\text { Revised: August 16, } 2018 \\
\text { Accepted: August 30, } 2018\end{array}$ & $\begin{array}{l}\text { With the development of internet technology, mobile-learning models began to be } \\
\text { developed. M-learning is a conventional form of learning as outlined in digital format } \\
\text { through internet technology. This system can be used in distance learning or } \\
\text { conventional learning. Therefore developing this model does not merely present } \\
\text { subject matter to the internet but needs to be considered logically and holds the } \\
\text { principles of learning. Likewise, the development design that is simple, personal, and } \\
\text { fast, and the element of entertainment will make students feel convenience studying in } \\
\text { front of the internet as if they were learning in class. }\end{array}$ \\
\hline
\end{tabular}

Fiqh science learning

Innovation

\section{INTRODUCTION}

Technology is currently rapidly developing especially information and communication technology. This makes humans inseparable from the distance of space and time [1]. With the development of increasingly advanced technology, humans can make various kinds of equipment as a tool in carrying out various activities to support productivity. An example is mobile technology where mobile phone users are increasing from year to year [2]. In Indonesia, according to the Nielsen survey, the number of mobile users as of May reached 125 million people out of 238 million residents. Android provides an open platform for developers to create their own applications for use by a variety of mobile devices. This operating system has a bright future thanks to the support of thousands of independent software developers.

From the Figure 1, it can be seen that the market share in the 2012 mobile of Android around 59\%, it is far greater than other Mobile OS so that there will be more mobile device manufacturers that include Android in their devices. The ability of mobile devices to support computer applications is very dependent on the operating system it uses. There are five operating systems that are widely used on mobile devices today, including Windows Mobile, Symbian OS, Android, Blackberry and iOS. Android is the first open source mobile platform developed by several software companies, especially Google Inc. Android is a software stack for mobile devices that contains an operating system with a Linux kernel, middleware and key applications. Android provides an open platform for developers to create their own applications for use by a variety of mobile devices [3]. This operating system has a bright future to the support of thousands of independent software developers.

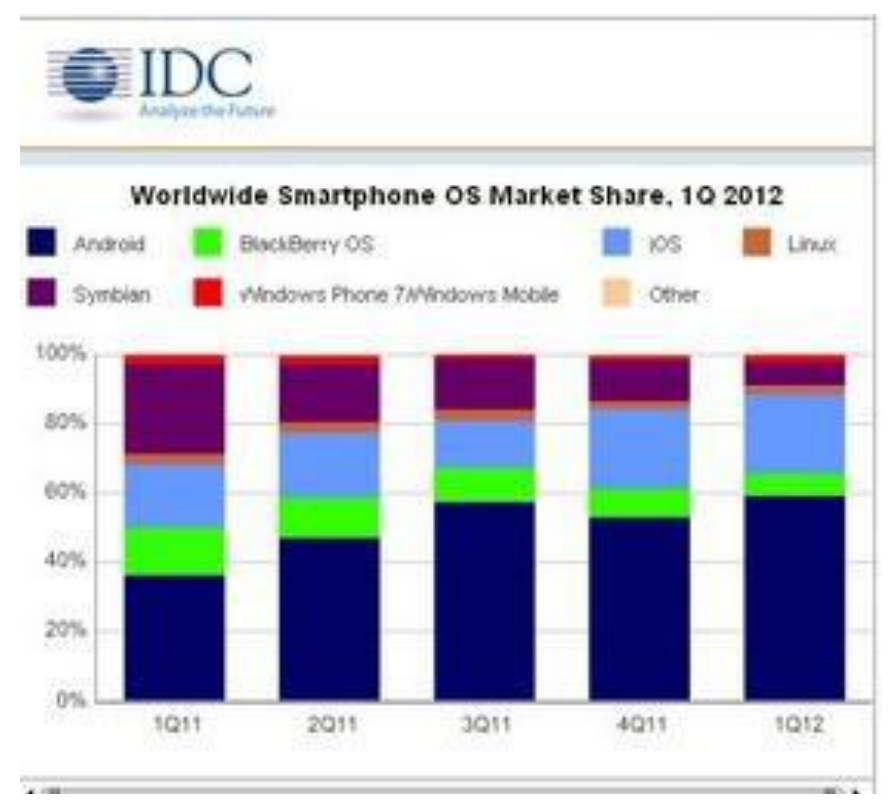

Fig. 1. Smartphone OS survey 
Furthermore, it can also use to learning activity known as a mobile learning system. This system allows users of mobile devices, for example mobile phones, to conduct teaching and learning activities wherever and whenever. This is also supported by a survey where most of the cellphone voters are dominated by teenagers.

From Figure 2, it can be seen that the most smartphone users are around 53\%, aged 18-27 years, which is dominated by high school and university students. Where the average mobile phone has sophisticated features.

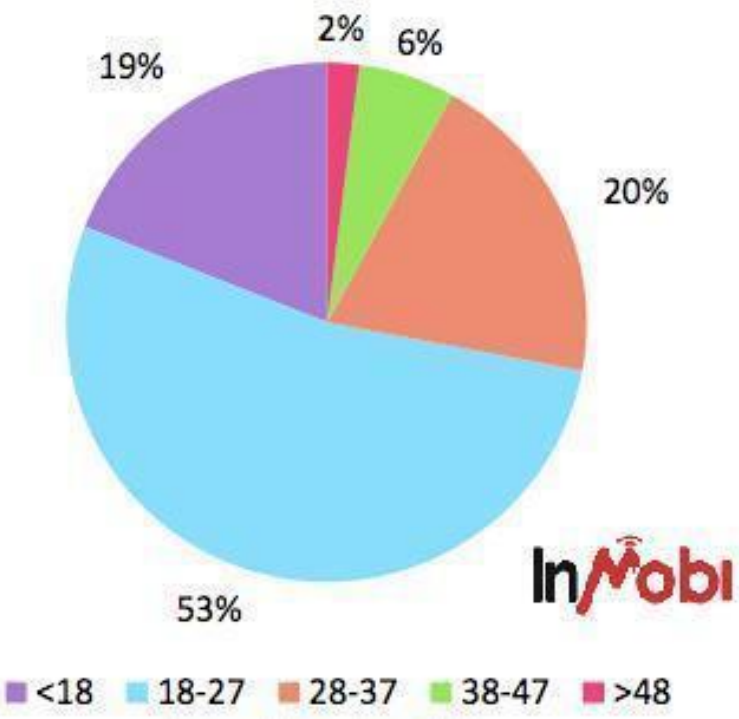

Fig. 2. Indonesia mobile web user survey

\section{FIQH SCIENCE}

Fiqh is a basic tool and important for every Muslim. It in detail regulates the behavior of human life, both in terms of worship and muamalah for a lifetime. Therefore, it becomes compulsory for every Muslim to learn fiqh. Even, one devotee and fiqh expert is more feared by Satan more than a thousand worshipers who do not understand fiqh. In Indonesia, discussing of fiqh cannot be separated from Madzhab AsyShafi'i which is the largest Madzhab. So, learning about Madzhab Asy-Shafi'I becomes very necessary. It very famous among the Islamic student. They are willing to spend years in the Islamic boarding school to learn it.

In the teaching and learning activities, it use a book called the yellow book which usually implements direct interaction from the teacher, students and learning resources. The learning approach use a Sorogan method, which means that students reading the yellow book in front of the religious teachers who directly witness the validity of the students reading, both from context and language. In addition a Bandongan which means that student collectively listen to the readings and explanations of the teachers while each make a notes to the book.

\section{MOBILE LEARNING}

Mobile Learning is a method that uses wireless and mobile technology for education by expanding access to online-based desktop environments to mobile devices [1], [4], [5]. Mobile learning systems have three main domains, namely the features provided by mobile phones or the, wireless technology, and electronic learning systems [6], [7]. Mobile learning system architecture, consisting of three layers that are interconnected, namely e-learning Management System (eLMS), mobile learning Management System (mLMS) and delivery media.

The existence of Android-based Mobile Learning can support student learning and make it easier for teachers to monitor student learning processes. It is expected that with the mobile-based learning media, Muslims in particular for students can learn the Science of Fiqh and its guidance more practically and easily anytime and anywhere without limitation of time and place so that learning can be carried out effectively, and efficiently in order to achieve the planned objectives .

\section{ANDROID PLATFORM}

Android is a subset of software for mobile devices that includes the operating system, middleware, and core applications released by Google [8], [9]. While the Android Software Development Kit (SDK) provides the tools and APIs needed for Android applications that will not run directly on the operating system kernel but will run on Dalvik. It is a virtual machine specifically designed for use on embedded systems, developing applications on the Android platform with using the Java programming language. Android provides various features and APIs that allow access to various features of mobile devices. These features such as:

- Framework application that supports component replacement.

- Dalvik virtual machines that run on the Linux kernel and are optimized for mobile devices.

- Integrated browser based on the open-source Webkit engine.

- Optimized graphics supported by customized 2D graphics libraries, 3D graphics based on the OpenGL ES 1.0 specification (Optional hardware acceleration).

- SQLite for data storage.

- Media support that supports audio, video, and images (MPEG4, H.264, MP3, AAC, AMR, JPG, PNG, GIF)

- GSM telephony (depending on hardware).

- Bluetooth, EDGE, 3G, Wifi (depending on hardware).

- Support enhancements such as GPS, camera, touch screen.

- Multi-touch is a capability that allows to use two or more fingers to interact with the device. 
- A complete and rich development environment including emulator tools, debugging tools, memory profiles and performance, and plugins for Eclipse IDE.

- The market that functions as a selling point for Android applications

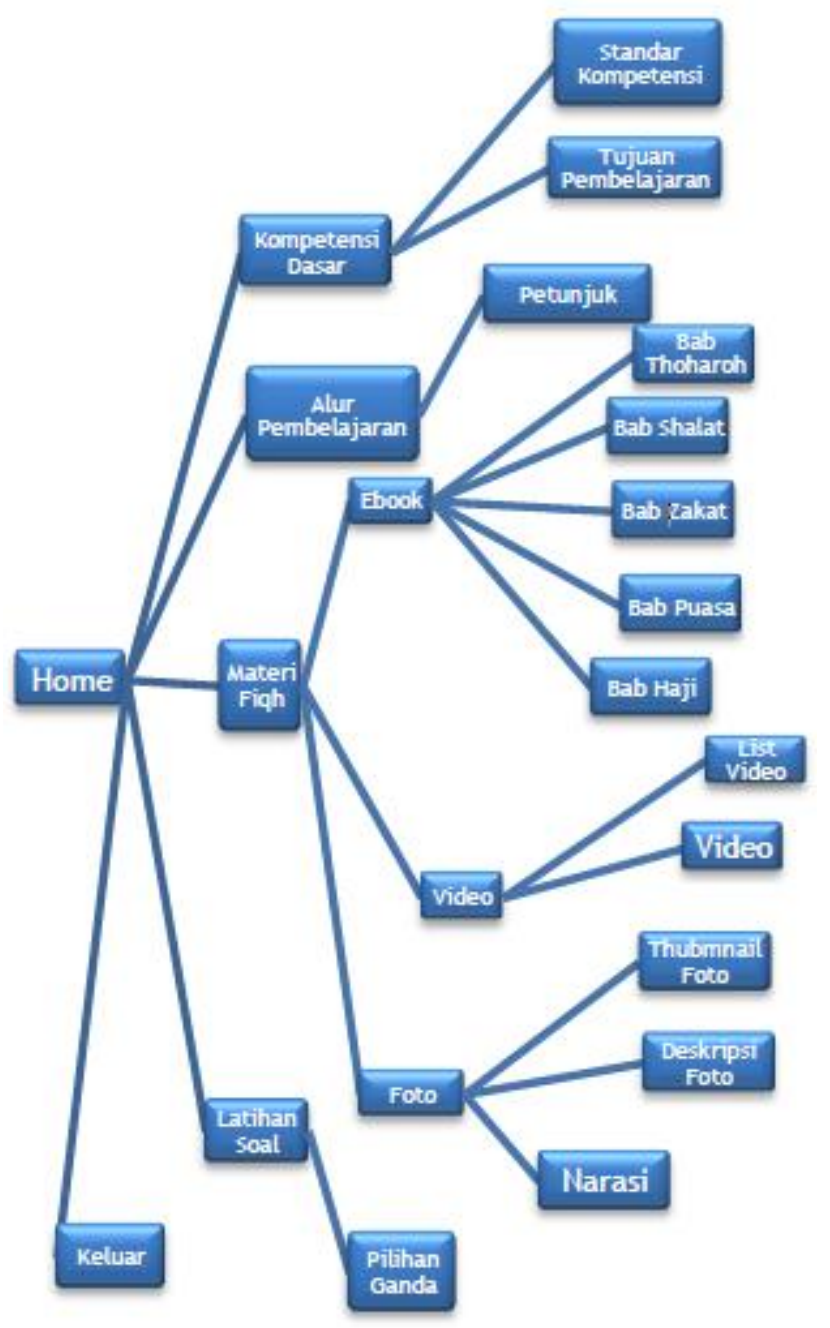

Fig. 3. Architecture design

\section{CONCLUSION}

The policy of educational institutions in utilizing internet technology towards m-learning needs in-depth study. Mlearning is not merely transferring all learning on the internet. The essence of m-learning is a learning process that is assisted through internet technology.

\section{References}

[1] C. P. Lim and D. Churcill, "Mobile learning," Interact. Learn. Environ., vol. 24, no. 2, pp. 273-276, 2016.

[2] B. Eschenbrenner and F. F. H. Nah, "Mobile technology in education: uses and benefits," Int. J. Mob. Learn. Organ., vol. 1, no. 2, pp. 159183, 2007.
[3] N. Gandhewar and R. Sheikh, "Google Android: An emerging software platform for mobile devices," Int. J. Comput. Sci. Eng., vol. 1, no. 1, pp. 12-17, 2010.

[4] U. Farooq, W. Schafer, M. B. Rosson, and J. M. Carroll, "M-education: bridging the gap of mobile and desktop computing," in Proceedings. IEEE International Workshop on Wireless and Mobile Technologies in Education, 2002, pp. 91-94.

[5] Y. Mehdipour and H. Zerehkafi, "Mobile Learning for Education: Benefits and Challenges," Int. J. Comput. Eng. Res., vol. 3, no. 6, pp. 93-101, 2013.

[6] A. Mostakhdemin-Hosseini and J. Tuimala, "Mobile learning framework," in IADIS International Conference Mobile Learning, 2005, pp. 203-207.

[7] R. S. Cobcroft, S. J. Towers, J. E. Smith, and A. Bruns, "Mobile Learning In Review: Opportunities and Challenges for Learners, Teachers, and Institutions," in Proceedings Online Learning and Teaching (OLT) Conference 2006, 2006, pp. 21-30.

[8] A. K. Saha, "A Developer's First Look At Android," 2008.

[9] J. Liu and J. Yu, "Research on development of android applications," in 4th International Conference on Intelligent Networks and Intelligent Systems, 2011, pp. 69-72. 